\title{
НОВИ ПОГАЕАИ НА СРПСКУ НАУКУ О КЬИЖЕВНОСТИ
}

\author{
(Јован Пејчић Пуйеви срӣске науке о књижевностии, \\ Српска књижевна задруга, Аесковачки културни центар, \\ Београд, 2020)
}

Монографија Јована Пејчића (1951) Пуиееви срйске науке о књижевно$c \bar{u} u$ на четири стотина страница, осим уводних и закьучних разматрања, бележака о књизи и аутору, списка митературе, доноси и Аванаест текстова подевених у три погмавња: „Основи“, „Печати“, и „ОАноси, сусеАства, Аичности“. Монографија није настајала по априорном циьу, већ је проистекла из вишегодишњег истраживања и књига: Простиори књижевної gуха (1998), Почеци и врхови (2010) и Зрна, расаg, жееива (2015), компонована као таква преАставьа целовито књижевноисторијско и критичко разматрање тематике и проблематике српске историје књижевности и књижевне критике на путу ка стварању јеАне нове историје српске књижевности. Она икуструју стање и актуелни погмеА на историју српске књижевности, науку о књижевности и књижевност.

У том контексту Пејчићева монографија упућују и на статус и моћ књижевне критике као културе и наслеђа и могла би се поредити са монографијама Петра Мияосавьевића (1937) Сисиием срйске књижевносиии (1996), која Ааје претпоставке и заАатке за заснивање новог система српске књижев-

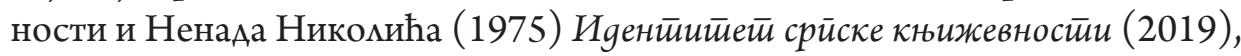
која преАставља врхунски домет у разматрању елабориране проблематике, битне за критичко разматрање историје српске књижевности. У овим монографијама су означени идентитет српског народа и културе и основе из којих се развила књижевна критика. ${ }^{1}$

1 Видети више у: Ана Мумовић, Прейлеg истиорија срӣске књижевносӣu, Институт за српску културу -Приштина/ Аепосавић, 2021, стр. 341-361. 
Пиодоносни историчар књижевности и књижевни критичар Јован Пејчић $^{2}$ је у процесу критичког превредновања у Пуйевима срйске науке о књижевностии кренуо оА суштинског питања - начела науке о књижевности и пробкема разврставања, које је у основи сваке историје српске књижевности. Проблем је свео на суштинску меру и оцену, на три начека: начело афирмачије (1), начело акииуализачије (2) и начело йроблемайизачије (3). Свако начело представьа кьуч који отвара поље посебне Аисциплине. Текстови у којима Аоминира начело афирмације односе се на књижевну критику. Текстови књижевноисторијског смера су они у којима је доминантно начело актуализације. У теоријским, естетичким и књижевно-философским текстовима разматра се начело проблематизације. Али, свако оА наведених начема, истиче аутор, има и своју Аругу, супротставьену страну. Тако је начелу афирмације супротставьено начело негације; начелу актуализације начело неутрализације, док је супротна, иако невидьива страна начела проблематизације, начело канонизације. Иако, самостална, ова начема нису довољна сама себи. Ј. Пејчић подвлачи њихову међусобну повезаност и упућеност. Аакме, реч је о приступу који чини основу науке о књижевности, подјеАнако битном за историју књижевности и књижевну критику, и отуда његов закьучак: „свако оА поменутих начела преАставьа кьуч, односно отвара поље засебне митерарне Аисциплине - на пример критичке, или књижевне иситорије

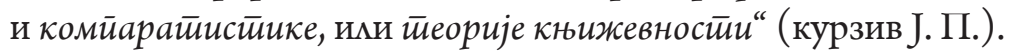

У тим начелима, уверен Аа савршених подела у историји књижевности нема нити може бити, Пејчић трага за основним смислом књижевне историје и књижевне критике и налази смисао сличносиии и зајеgничко језіро или основне вреgностии, йрајања и јеgинсииво књижевноі и националної ияен$\bar{u} u \bar{u} e \bar{u} a$. На то упућују основни знаци из наслова радова поглавьа књиге поА насловом „Печати“: смисао и сличности историје и књижевне критике, јединство књижевног и националног идентитета, веза и однос књижевног критичара и књижевног историчара и основи, вредности и границе распростирања националне књижевности и њеног трајања.

Када су у питању основни путеви развоја историје српске књижевности, примерено трима начемима означеним у приступу, Пејчић закьучује Аа основу српске науке о књижевности преАставњају: мит о прекиАу и развоју српске књижевности настајале на више језика (1), потрага за почецима српске књижевне критике и есејистике (2), проблем периодизације као утемеьујуће идеје српске историје књижевности(3) и њено рађање (4).

2 J. Пејчић је приредио и критичким коментарима опремио више дела српских писаца, између осталих Јована Скерлића (пет књига), Никанора Грујића, Исидоре Секумић, Богдана Поповића, Милана Ракића, Аазе Костића, Вцадислава Петковића Аиса, Микутина Бојића, Јустина Поповића, Бранимира Ћосића, Радета Араинца, Николаја Тимченка, као и критички зборник репрезентативних радова о Фубомиру Недићу. То су чињенице првога реда које указују на карактер његових истраживања и оцена. 
Познато је да је Аоминантна књижевна појава с краја XVIII и на почетку XIX века био Аоситеј Обрадовић, писац који је „на велика врата увео народни језик у српску књижевност“. Стварајући на Ава језика, он је „коначно потврАио мост“" између старе и нове српске књижевности, који је, пре њега, успоставио Гаврил Стефановић Венциовић, као први и послеАњи српски књижевни посленик који пише на Ава језика, српскословенском и народном, а с којим се гаси средњовековна традиција српске Аитературе. Јован Пејчић је Аошао и Ао сазнања о пионирском доприносу Аукијана Мушицког у периодизацији српске књижевности и на тај начин умногоме обогатио досадашњу научну преАставу у области историографије. И то су основни знаци из наслова Пејчићевих Пуйева срйске науке о књижевносиии оивичених у поглавьу „Основи“.

Јединство књижевног и националног иАентитета, што се може наћи као најмањи заједнички именилац свих историја српске књижевности, Пејчић је пластично показао на примеру анализе формата дела и стваралачке мичности Јована Скермића као књижевног критичара и књижевног историчара. Апострофирао је, између осталог, и основно полазиште које указује на везу и оgнос историје и књижевне критике и чињеницу Аа књижевна критика у историји књижевности има своје роgно местио. Скерлић пише Исйорију, како означава већ у уводу, „схватајући књижевност као највиши израз народног живота“.

Научни и књижевни профил Јована Скерлића приказивали су у минумом веку многи критичари. У јеАном широком регистру нанизани ти судови би се, по критичкој рекапитулацији Ј. Пејчића, могли свести на слеАећу мествицу вредносних оцена: нашао се на не узораној кедини српске књижевности; бринуо је Аве главне бриге целе српске културе; остао је појава у народном животу која одавно и Аалеко премаша границе своје епохе и остварује Аруштвену моћ коју дотме нико није имао у српској култури; био је моралист, просветитељ и Аруштвени реформатор, национални борац и иАеолог са широким утицајем; у окрутним условима у борби са окрутним противницима и сам је био окрутан (Петар Џаџић); Скерлићева појава стварана је вековима, низом преАака борбене и убојите природе; он је критичар и историчар у Србији која се спрема за херојске подвиге: „освету“ Косова, ослобођење Старе Србије, уједињење Српства, стварање балканске Аржаве Јужних Словена и те цињеве бране и подупиру он као централна природа своје средине и његова критика и историја књижевности у процесу тумачења опште историје. ЈеАном речи, био је „човек за смеле покушаје и тешке напоре“ (Слободан Јовановић) и припада низу који чине: Јован Цвијић, БогАан Поповић и ВАадимир Ћоровић.

J. Пејчић се бави и односом J. Скерлића према догматској и импресионистичкој критици. Тај однос именује као драматичан сукоб. На страни догматске критике Скерлићу су били туђи ставови Иполита Тена, Фердинанда Бринтјера, а на страни импресионистичке критике блиски су му били ставови Жила Аеметера, Анатола Франса, Жоржа Пелисјеа, Емила Енекена, Сент-Бева, Емика Фагеа и Пома Стапфера. 
Печат Пејчићевим Пуйевима Ааје и елаборација парцијалне Истиорије срйске књижевностии барокноі gоба (1970) Миморада Павића, историчара књижевности којег одређују синтезе и компаратистички метод у парцијалној историји књижевности, изложена после страница којима се окончава разматрање домета и значаја великог Скерлића. Пејчић мисли да Павића одређују два праваца истраживања: „ЈеАан оА праваца тицао се проучавања веза српских писаца са књижевностима европских народа. Аруги правац водио је ка истраживању и синтетичкој обради српске књижевности XVII, XVIII и раног XIX века.“

Пејчићев финални налаз да се Павићева синтеза заснива на томе Аа се сродна збивања представьају „у сферама историје народа, цркве, ликовне уметности, просвете и језика“, што произикази из Павићеве Истиорије, и аа се све то „враћа на поље историје књижевности“, што указује на то колико је важно разумети преглеА историја идеје из свих историја српске књижевности.

Као оријентир на путевима развоја српске науке о књижевности, значајна је и Пејчићева емаборација Истиорије срйске књижевносиии (1865) Павела Јозефа Шафарика (1796-1861). Имајући у виду чињеницу да је заснована на примарној чињеници Аа је пише странац (а странци су одувек били ослонци српске културе, не само када је реч о историји књижевности, већ и националној историји и свих Аругих културних области), и налазећи Аа је чувени Словак учинио „оАсудан корак“ у историји књижевности коА Срба, он резултантно пише: „Наслеђе српске књижевне историографије Авоструког је порекла. Решења потичу оА Аомаћих и иностраних историчара и тумача“. Као чињеница првога реАа, из које се може извести и вредносни суА, јесте сазнање Аа Ао појаве Шафарикове Истиорије у европској науци и књижевности није било дела које је Аало тако широку основу за проучавању језика, књижевности, културе и цивилизације, нарочито Јужних Словена, „коА којих је што се језичко-литерарних и повесно-Ауховних истраживања тиче, све бимо још у заметку“.

И о Прейлеgу истиорији срӣске књижевносӣи (1865), Аругог странца, руског слависте Александра Николајевича Пипина (1833-1904), који у целости и Аанас није преведен на српски језик, плодотворни књижевни критичар J. Пејчић каже Аа је он „у последњој четвртини деветнаестог века знатно утицао на изградњу комплетне слике о развојним токовима српске књижевности и културе“.

У историјама српске књижевности заједничка формула мепоте израсла је из грчких уметности. И критичари и књижевни историчари треба Аа оцењују тежећи размишьањима која обухватају усвојена мерика. Као и песник, у Аеку треба Аа виде, како је писао Јован Аучић, оно што „вреди бар за највећи део културних ьуди“, Аа знају да је проблематичан чин то када човек тумачи Аругог човека и Аа зато нико не сме Аа се баца каменом на „освештане вредности“времена и књижевне генерације.

Пејчићева синтеза у монографији Пуйеви срйске науке о књижевностии која има Ава паралелна тока: први, у основном тексту и Аруги, у фуснотама, 
које се могу читати као ӣpā̄eћa књиїа, или извесна допуна. Кьучна поставка којом се Јован Пејчић руководи у истраживањима, која је сабрао у ову стручну монографију садржана је у питањима: Шта у изразима „открити почетак“, „осветлити рађање“, „разумети трајање“, „утемеьити вреАности“ значе кьучне речи „открити“, „осветлити“, „разумети“ и „утемеьити“?

ОАговоре на ова, као и низ Аругих суштинских питања, налазимо у првом Аелу књиге. Историчар књижевности се пита: Аа ми је преласком српске књижевности из старосрпског на вуковски језик изазван прекиА у њеном развоју? Како се српска књижевност Аелима на периоде и покрете и које су кьучне идеје тих периода? КаАа код Срба почиње да се јавьа књижевна критика као самостална научна Аисциплина и ко су њени зачетници? КаАа и како се развија есејистика у српској науци о књижевности и гАе почиње и како се развија српско беседиштво? Када и како се развија историја књижевности као самостална обцаст проучавања?

Аруги део монографије Аоноси анамитичке расправе о научном Аоприносу најзначајнијих српских критичара и историчара митературе. Осветьени су ставови и дела Захарије Орфекина, Аукијана Мушицког, Павела Јозефа Шафарика, Стојана Новаковића, ьубомира Недића, Јована Скермића, Тихомира Остојића, Ђорђа Трифуновића и Миморада Павића. И у питањима које смо навеки и у аналитичким расправама Пејчић је означио свој пут и циљ проучавања српске историје књижевности. Његови Пуйеви су, ван сумње, јединствена књига ка новој историји српске књижевности у којој књижевна критика осваја нови простор.

Тај пут је Ауг, Аавно започет и овом монографијом се природно наставља.

На том путу Пејчићевим Пуйевима срйске науке о књижевносиии, у овом часу, припада значајно место, јер представља најновији поглеА на историју српске књижевности и њен критички Аух и чин као грађевину науке која расте и чије темеве треба изнова утврђивати.

Пре више оА Ава века Шеминг је писао Аа „већина ьуди изгледа не зна ни за какву прошлост, осим оне која се у сваком тренутку што протиче управо за тај тренутак увећава и која очиглеАно сама још није прошла, тј. није одвојена од садашњости“.

Пејчићев критички Аух парахемно указује и на прошии и на садашњи тренутак српске књижевне мисли. Као такав он је и могуће исходиште у стварању новог погледа на историју српске књижевности и критике и Аомете садашњих књижевних историчара и критичара. 